\title{
A Case Study on Sustainability Analysis of Fisheries in Pangandaran, West Java Province
}

\author{
Atikah Nurhayati $^{1}$ and Agus Heri Purnomo ${ }^{2}$ \\ 1. Faculty of Fisheries and Marine Sciences, Padjadjaran University, Bandung 45363, Sumedang West Java Province, Indonesia \\ 2. Research Center and Development for Marine and Fisheries Processing and Biotechnology, Agency for Marine and Fisheries \\ Research and Development, Jakarta 10260, Indonesia
}

Received: November 22, 2013 / Published: April 20, 2014.

\begin{abstract}
This research was to assess the sustainability of fisheries in Pangandaran, West Java. This fishery is an important one in the region, but is threatened by increasing over-exploitation which has led to a steady decrease in the production. In addition to over-exploitation problem, a record of tsunami disaster makes this fishery a unique case. This research, based on a set of primary and secondary data was carried out using the Rapfish analytical approach. Primary data were collected using a stratified cluster random sampling technique, where as many as 186 outboard fishing operators were selected. Meanwhile, relevant complementary data were solicited purposively from five employees of Pangandaran Marine and Fisheries Service. Following from the Rapfish approach, it was found through this research that sustainability levels of fisheries in Pangandaran fall into poor category. For all types of fisheries that exist in the region, almost all sustainability dimensions namely ecological, social, technological and ethical dimensions were scored below 50 of the 100 maximum values. This paper concludes with a suggestion, pointing out attributes that should receive government attention in order that the sustainability of the fisheries in the future.
\end{abstract}

Key words: Sustainability, Rapfish, fisheries.

\section{Introduction}

Management of fisheries resources comprises various factors which are interrelated and affect their current functions and services to human beings. Among others there are economic activities in coastal areas, which generally involve other sectors, marine tourism, agriculture and industrial sectors. Such economic activities, in many places including in Pangandaran lead to severe environmental degradation that threatens its sustainability of existence, services and functions [1]. Destructive processes such as sedimentation, coral mining and mangrove deforestation are some common examples of coastal economic activities that cause negative impacts to the nature and its services and functions. These capitalize

Corresponding author: Atikah Nurhayati, Ph.D., research field: socioeconomic fisheries and marine. E-mail: atikah.nurhayati@unpad.ac.id. the detrimental effects of irresponsible fishing practices that cause imbalanced ecosystem condition.

Co-management is defined as the sharing of responsibilities between governmental institutions and groups of resource users [2]. Parametric management from fisheries around the world suggested that many "traditional" management systems that had successfully sustained fisheries were based on such parametric controls, which include protection of spawning and nursery areas, limited access, closed seasons and size limits. These management measures are often based on local or indigenous knowledge [3].

Pangandaran water is a part the Indonesian's Indian Ocean Fisheries Management Zone. This zone encompasses the waters of the Western tip of Sumatra Island and the South coast of Java Island. Pangandaran is a coastal sub-district in where tourism and marine capture fisheries are very important. These two sectors have major contribution not only to the 
district but also to the regional economy. Bojongsalawe coast is best representing the case and has been chosen as one of the study sites in this research. This site is well known for its surfing and other various tourist attractions, in the mean time, various types of normal natural shocks have brought economic stresses to particular groups in the community and lead to pressures to the resources [4].

The impact of the normal natural shocks is exacerbated by various forms of contemporary natural events. One example is the earthquake followed by tsunami that occurred in the region in July 2006, which destroyed much of the infrastructure and facilities owned by fishermen, including boat and fishing equipment. This has been perceived by many as a significant factor that influence the dynamic of fisheries in the area. Later, attitudes and actions of local economic actors unavoidably tend to be less friendly to the resources.

Fisheries resources, as mentioned earlier are very significant for Pangandaran economy and thus it is important to know how sustainable they are, particularly considering the existence of natural events described above. Following from Pitcher [5], dimensions of sustainability of fisheries include ecological, economic, ethical, social and technological dimensions. Based on the above, this research aims at assessing the levels of sustainability of fisheries in Pangandaran, focusing on these dimensions.

\section{Materials and Methods}

The data used in this research were collected using the survey method from both primary and secondary sources. Primary data were obtained through interviews with respondents representing community leaders and fishing boat owners (186 people) and the District of Ciamis Fisheries and Marine Service Officers (four persons). Secondary data were drawn from secondary sources including annual reports of relevant agencies/institutions.

Method of analysis used in this research, which aims to determine the level of sustainability of fishery, is the Rapfish technique (a rapid apprasial tehnique for fisheries). This technique applies the multi dimensional scaling (MDS) principles to assess the sustainability level of various dimensions of fishery resources. This technique is basically a statistical technique that performs a multidimensional transformation into is more simple dimensions [6].

The reason of choosing the Rapfish's MDS approach is its stability. The multi-dimensional approach to scaling in Rapfish gives stable results compared to dual variable method. All data of the attributes considered in this research were analyzed to determine the multidimensional point reflecting the position of the sustainability of fisheries based on two points of reference, namely the "good" point and the "bad" point. The following are the results of sustainability assessment for each fishery in the region [7].

In the MDS, two points of the same object is mapped in far-flung points. These points are very useful in regression analysis to calculate the "stress" that is a part of the MDS method [8]. Score on each attribute will form a matrix $\mathrm{X}(\mathrm{nxp})$, where $x$ is the number of areas and $p$ is the number of attributes used. A good model is indicated by the $S$-stress value smaller than 0.25 or $S<0.25$ and $R^{2}$ close to 1 . Index scales that assess the sustainability of the system have the interval of $0 \%-100 \%$. In this study, there are four categories of status of sustainability, as seen in Table 1.

\section{Results and Discussion}

Pangandaran districts are bordered by Ciamis in the North, Tasikmalaya in the West, Cilacap in the East and the Indian Ocean in the South. The coastal area surrounding this district belongs to six sub-districts. These are Pangandaran, Cimerak, Cijulang, Parigi, Sidamulih and Kalipucang. All of these six sub-districts have the potentials for both coastal tourism and fisheries. A general observation of this research indicates that tourism is booming in the area 


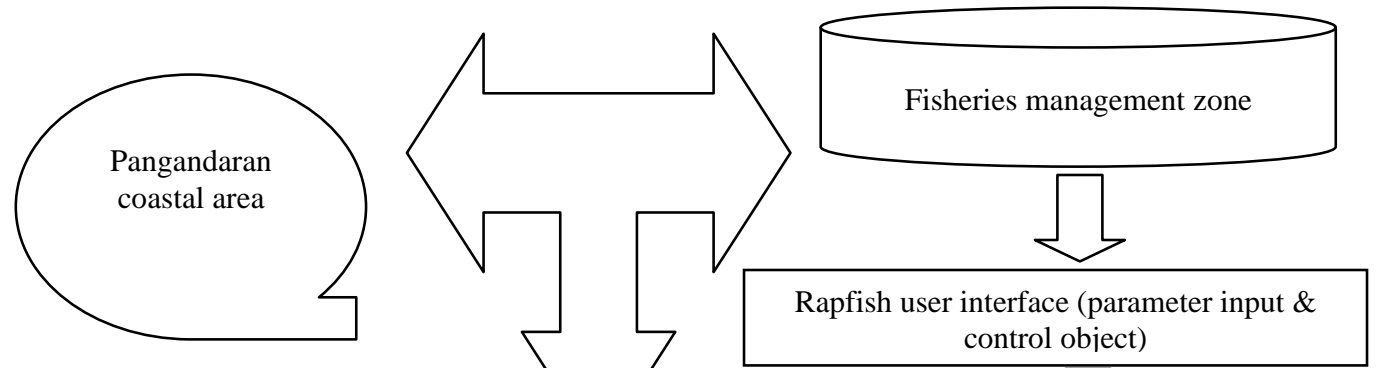

\section{Ecological}

(1) Exploitation status

(2) Recruitement variability

(3) Change in trophic level

(4) Migratory range

(5) Range collapse

(6) Size of fish caught

(7) Catch before maturity

(8) Discarded by-catch

(9) Species caught

(10) Primary production

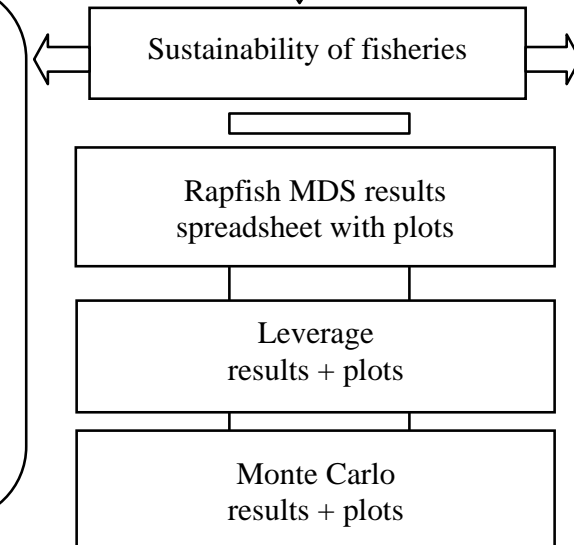

Economy

(1) Profitability

(2) Fisheries in GDP

(3) Average wage

(4) Limited entry

(5) Marketable right

(6) Other income

(7) Sector employment

(8) Ownership transfer

(9) Market

(10) Subsidy

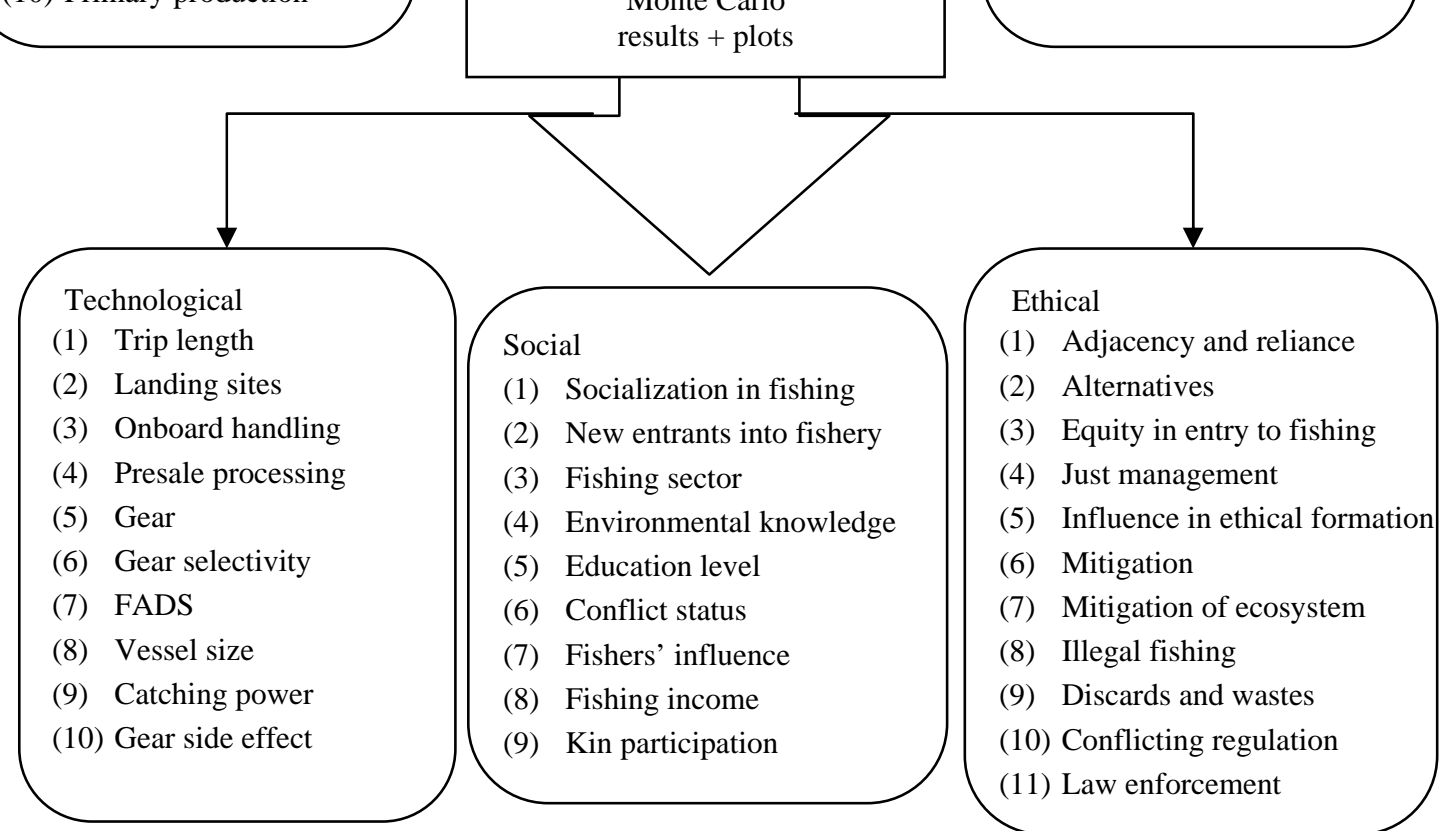

Table 1 Category index and status of sustainability.

\begin{tabular}{lll}
\hline No. & Index value & Category \\
\hline 1 & $0.0-25.00$ & Bad: not sustainable \\
2 & $25.01-50.00$ & Low: almost unsustainable \\
3 & $50.01-75.00$ & Sufficient: simply sustainable \\
4 & $75.01-100.00$ & Good: very sustainable \\
\hline
\end{tabular}

and has interfered with the interest of sustaining the capture fisheries industry. For the case of the six sub-districts mentioned above, the graphs below show the assessment that was made to compare different types of fisheries, each represents a different gear type. 


\subsection{Ecological Dimension}

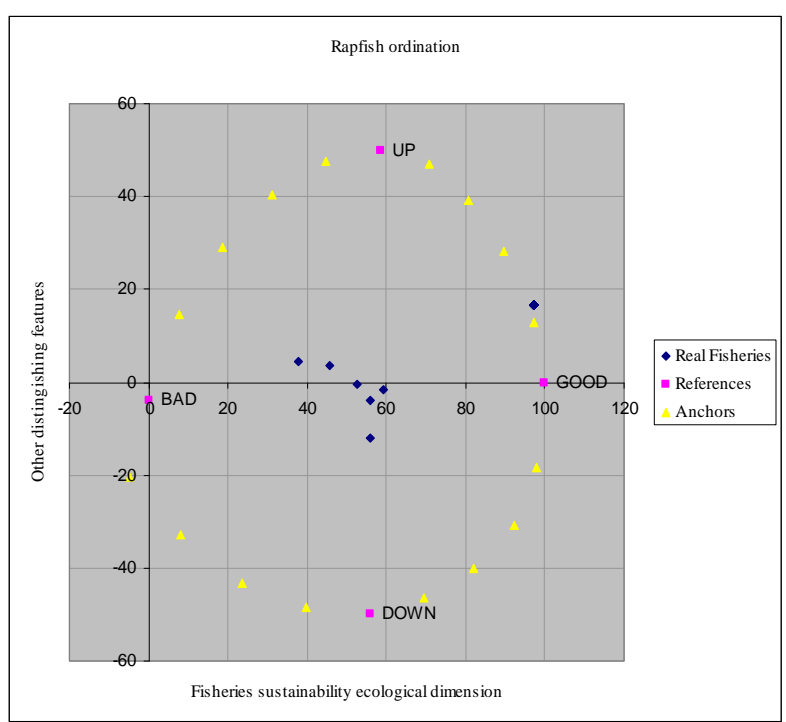

Fig. 1 Ecological rapfish ordination.

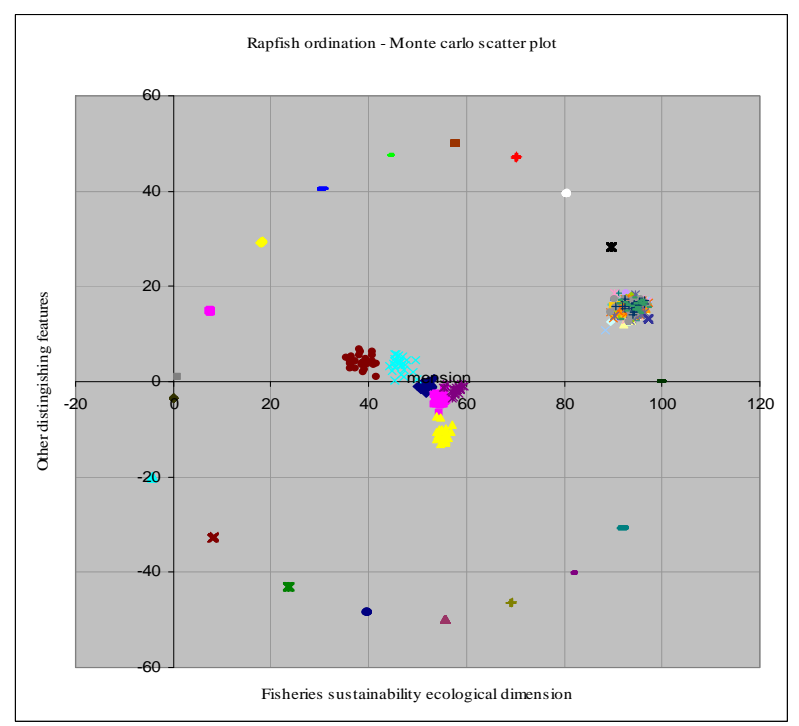

Fig. 2 Ecological monte-carlo scatter plot.

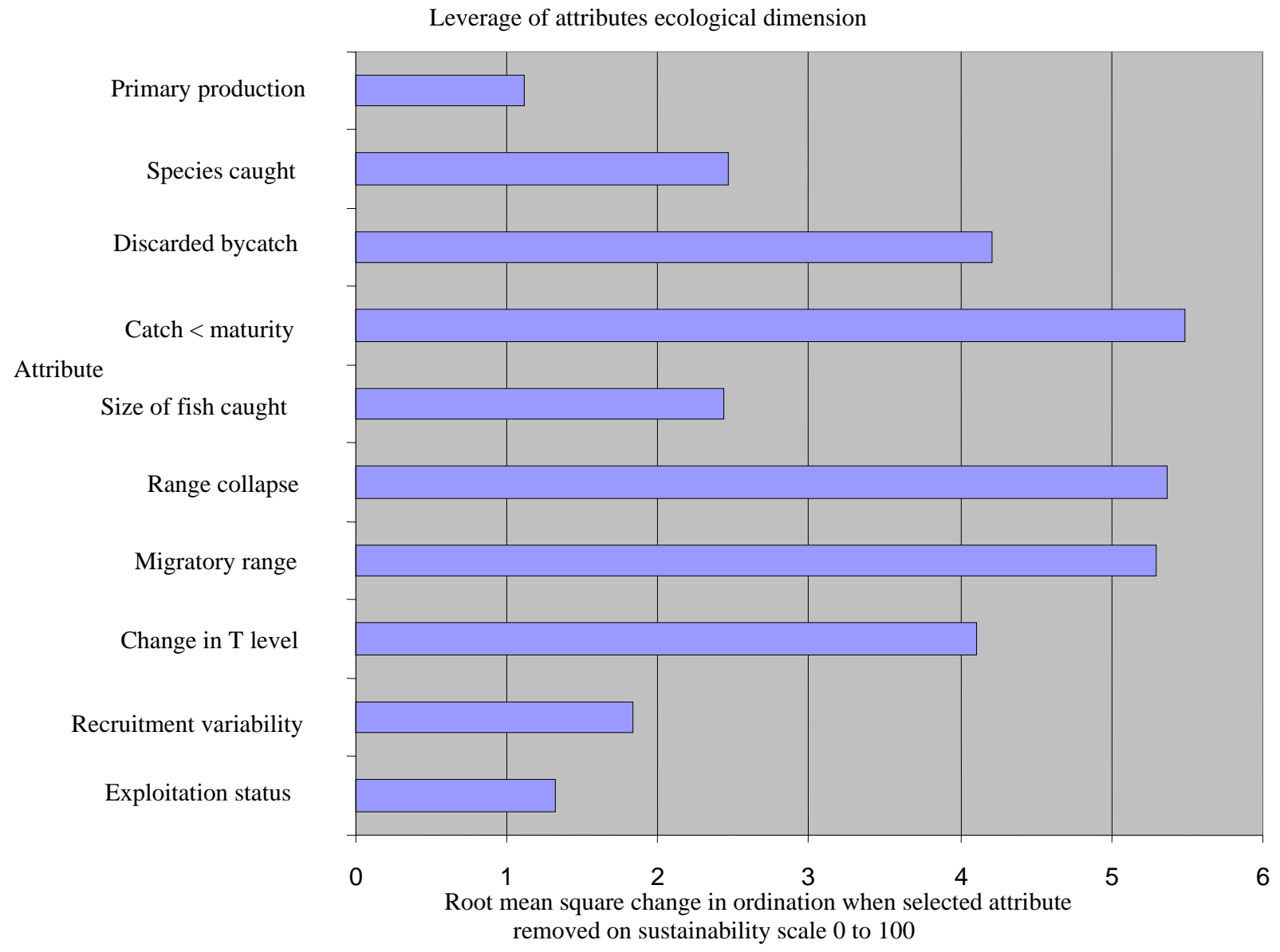

Fig. 3 Leverage analysis of ecological dimension. 


\subsection{Economic Dimension}

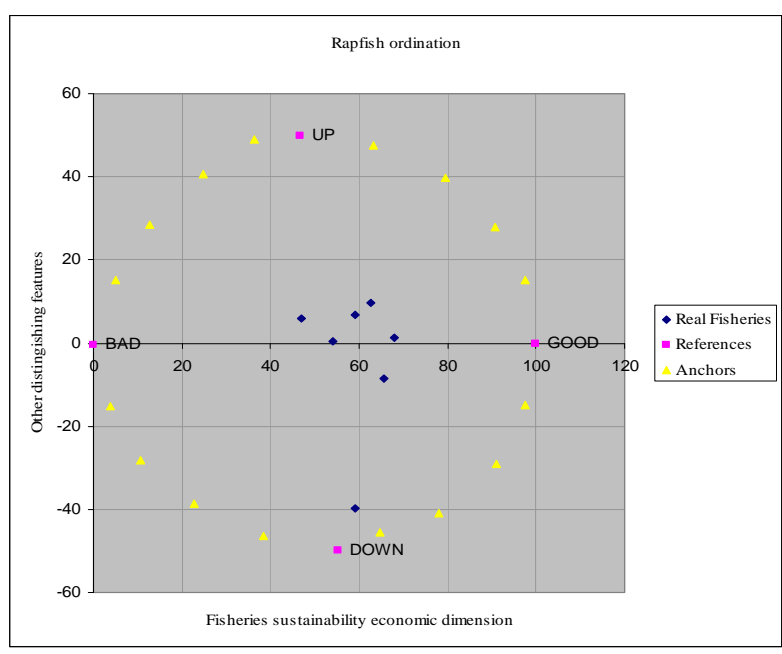

Fig. 4 Rapfish ordination of economic dimension.

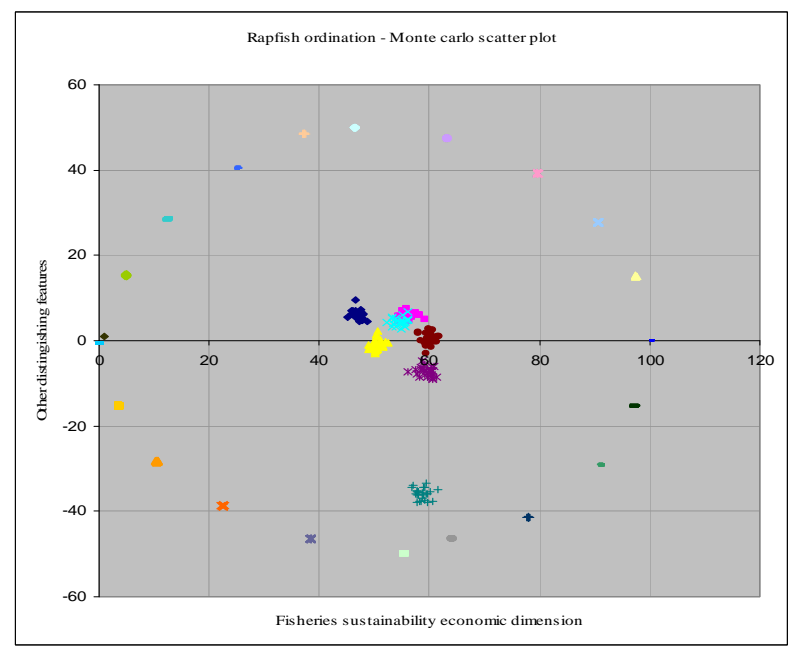

Fig. 5 Monte Carlo scatter plot of economic dimension.

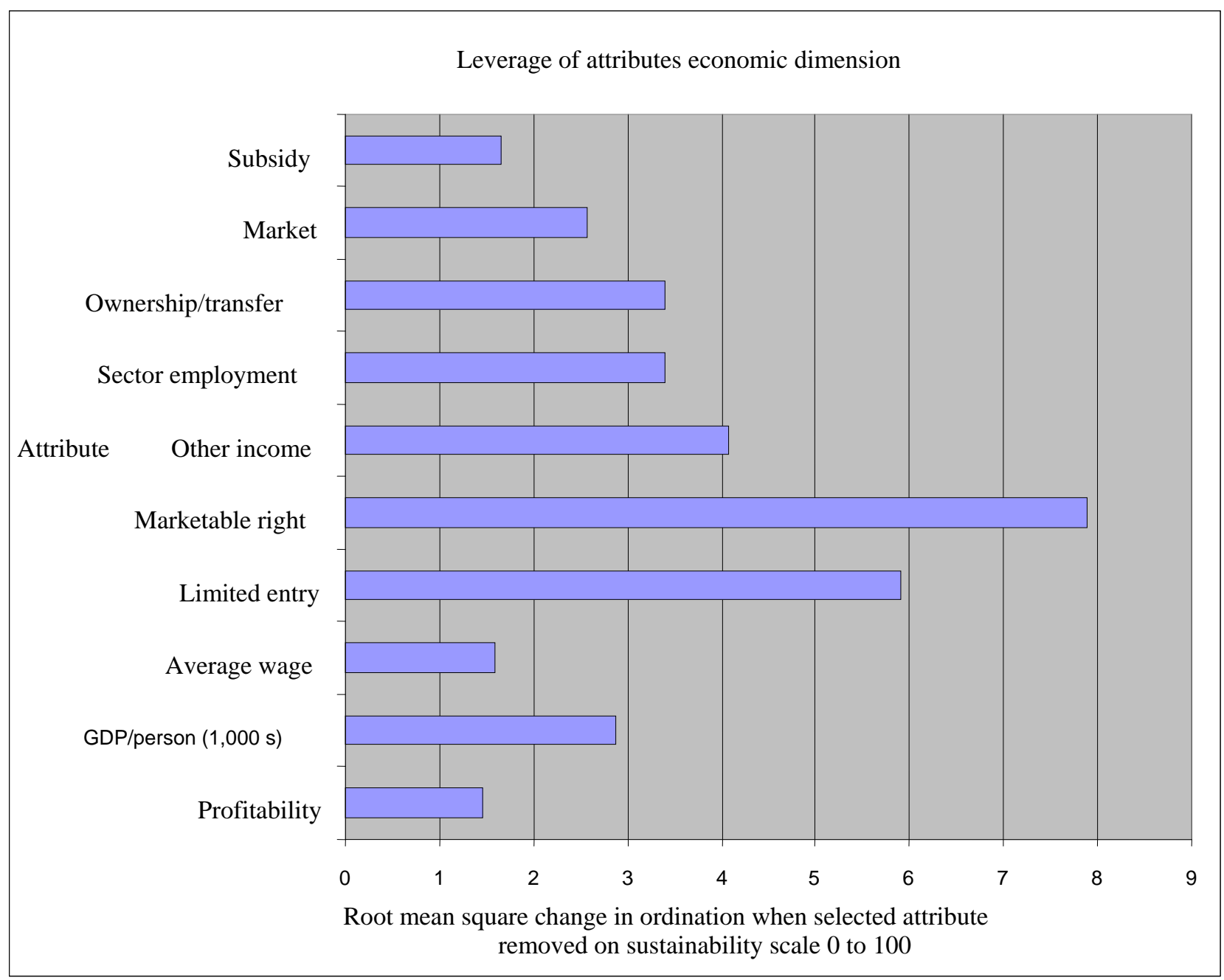

Fig. 6 Leverage analysis of economic dimension. 


\subsection{Social Dimension}

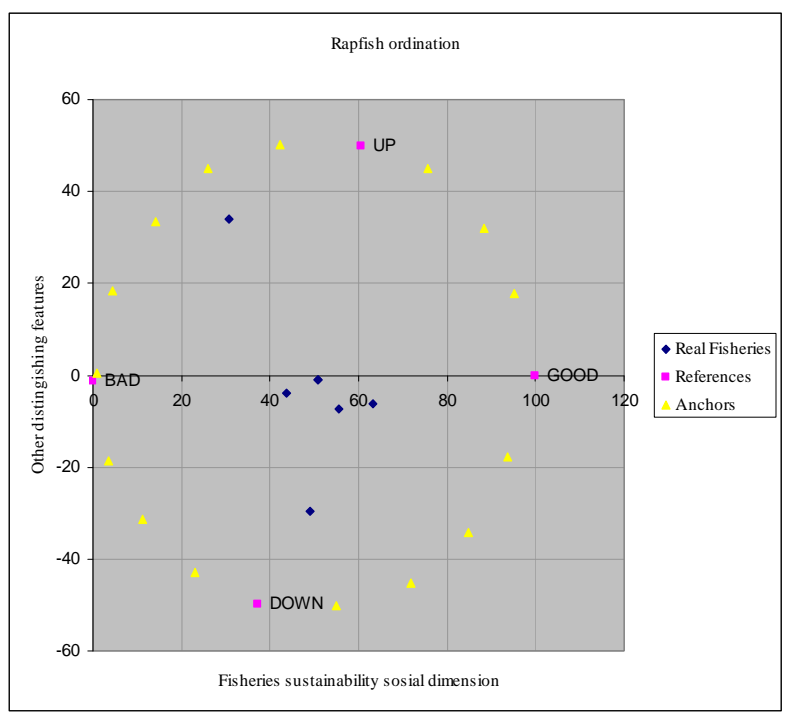

Fig. 7 Rapfish ordination of social dimension.

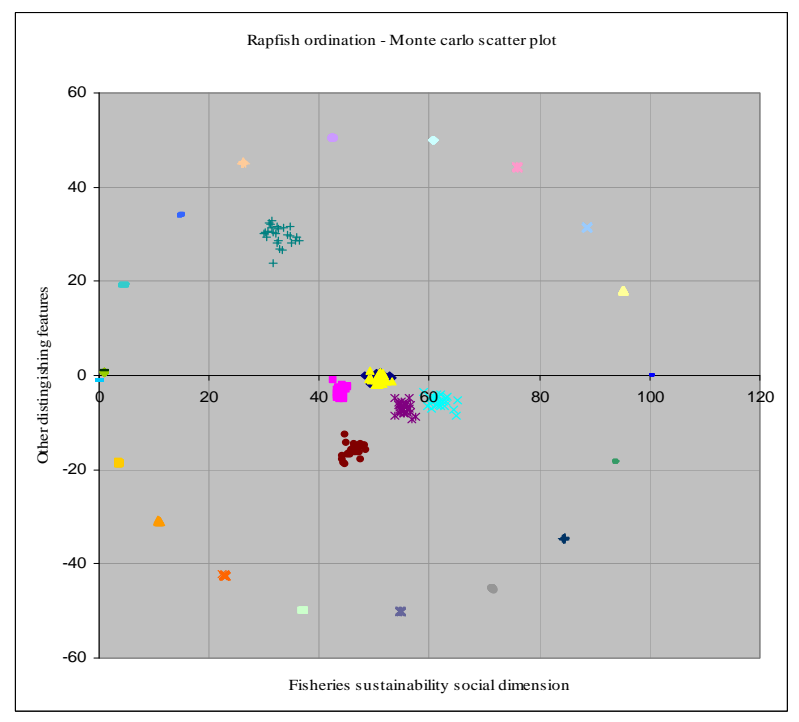

Fig. 8 Monte-carlo scatter plot of social dimension.

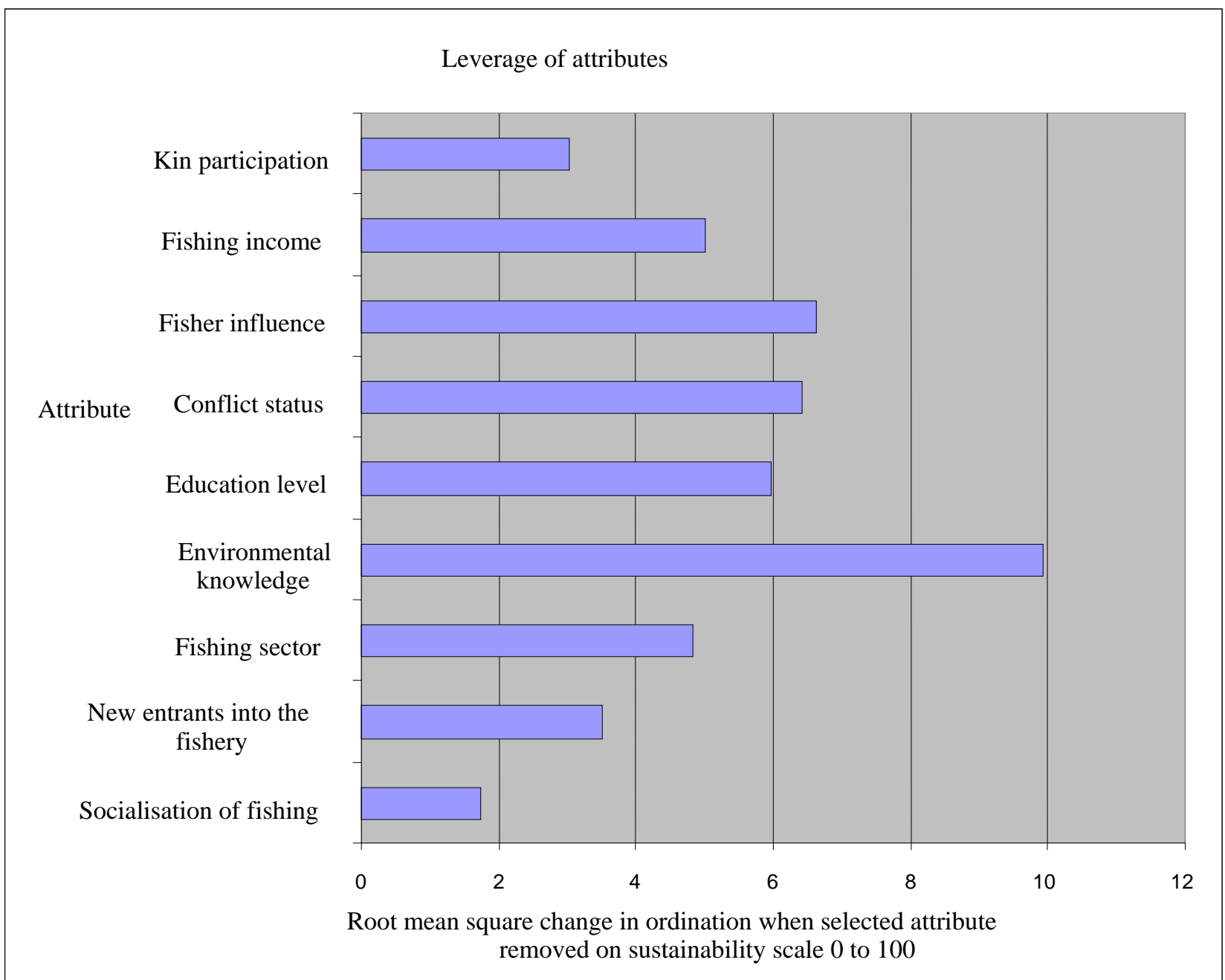

Fig. 9 Leverage analysis of social dimension. 


\subsection{Tecnological Dimension}

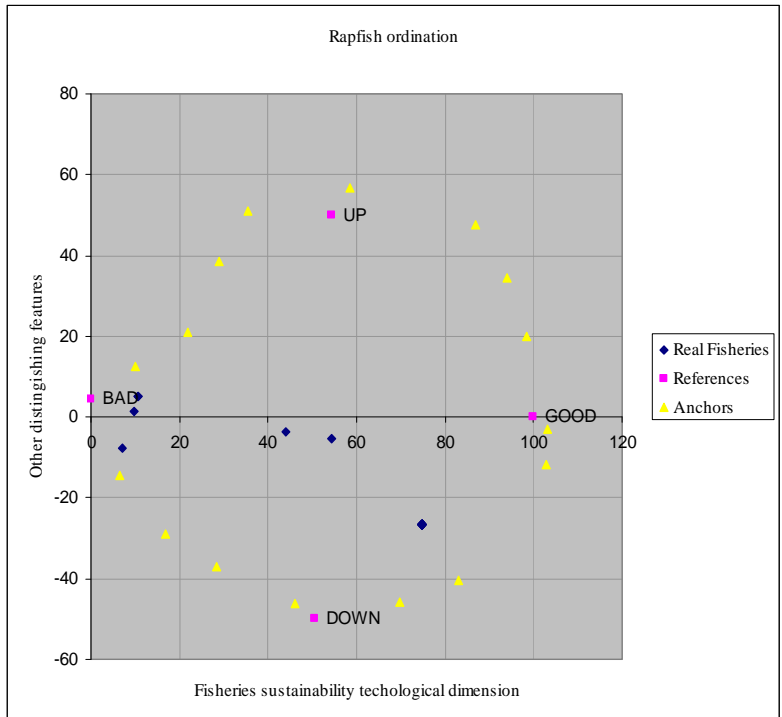

Fig. 10 Rapfish ordination of technological dimension.

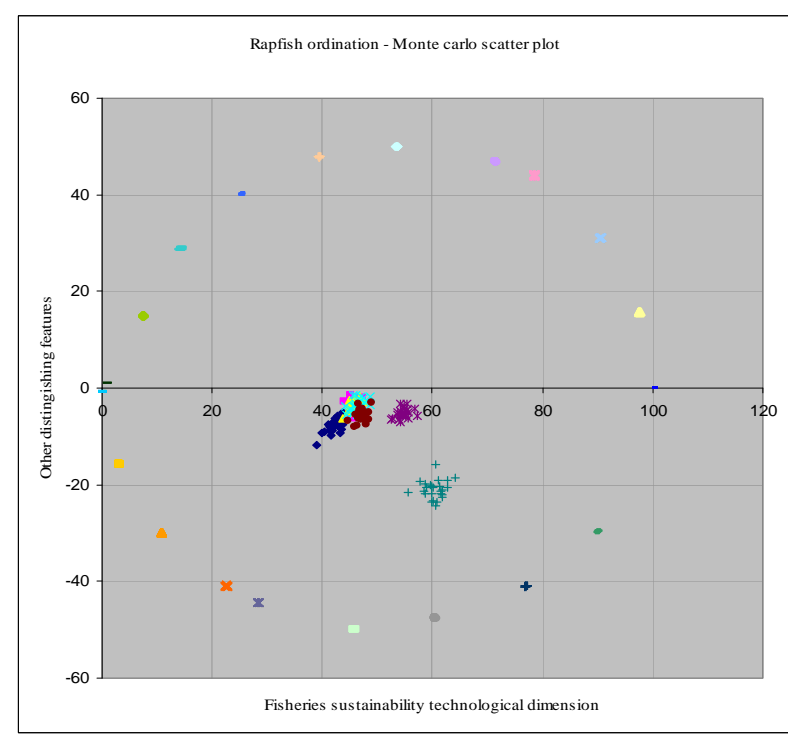

Fig. 11 Monte carlo scatter plot of technological dimension.

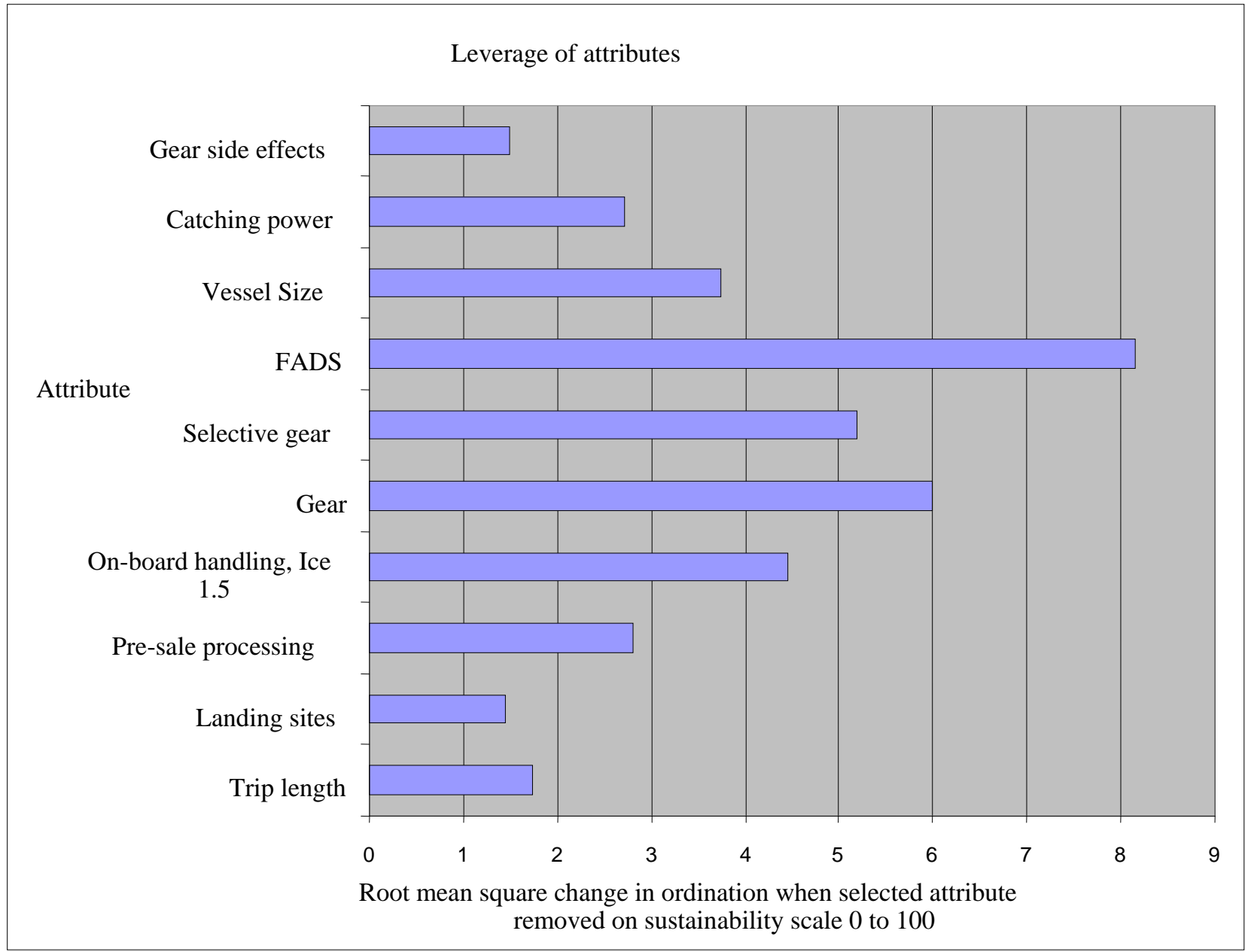

Fig. 12 Leverage analysis of technological dimension Simak Baca secara fonetik. 


\subsection{Ethical Dimension}

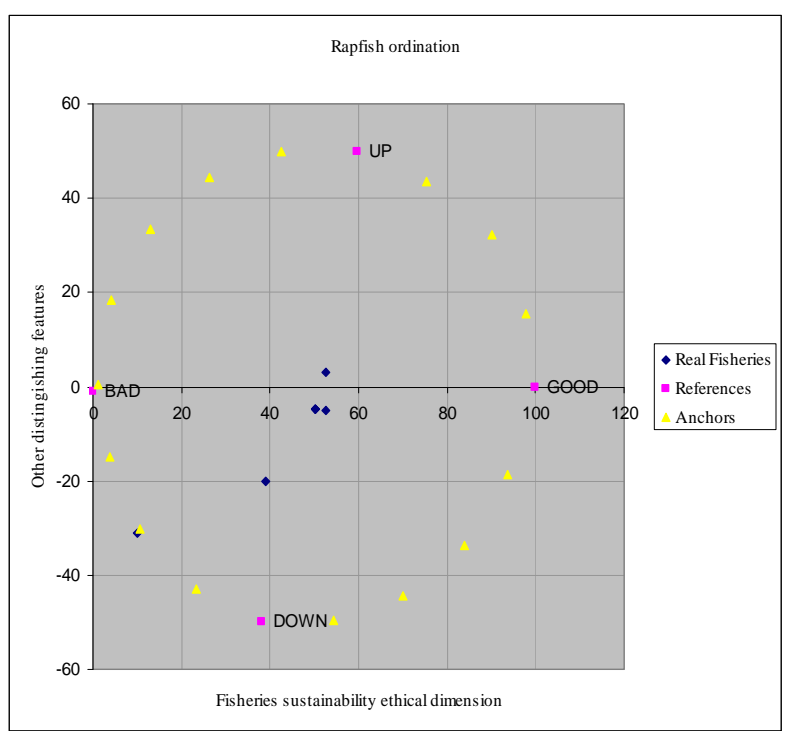

Fig. 13 Rapfish ordination of ethical dimension.

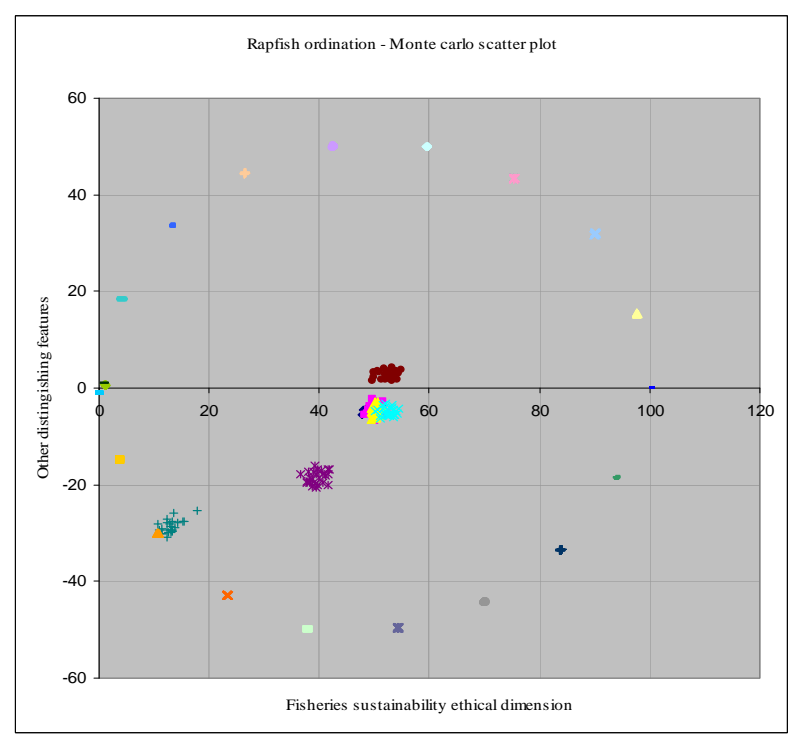

Fig. 14 Monte-carlo scatter plot ethical dimension.

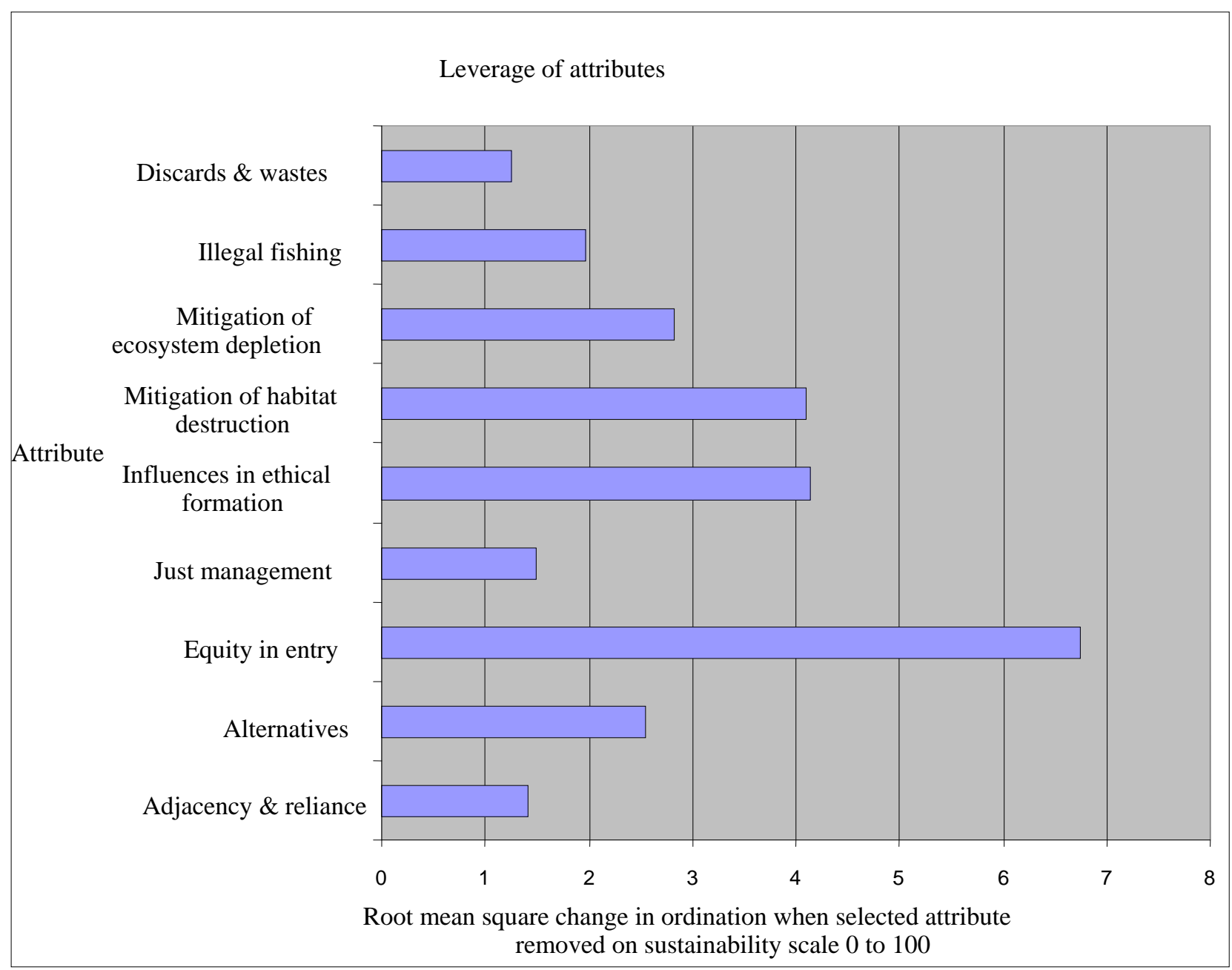

Fig. 15 Leverage analysis of ethical dimension. 
Table 2 Matrix of Pangandaran fisheries sustainability level sustainability.

\begin{tabular}{|c|c|c|c|c|c|c|c|}
\hline \multirow{2}{*}{ No. } & \multirow{2}{*}{$\begin{array}{l}\text { Type of fishing gear } \\
\text { Dimension }\end{array}$} & \multirow{2}{*}{$\begin{array}{l}\text { Demersal } \\
\text { danish seine }\end{array}$} & \multirow{2}{*}{ Beach seine } & \multirow{2}{*}{ Set gill nets } & \multirow{2}{*}{ Trammel nets } & \multirow{2}{*}{$\begin{array}{l}\text { Other drift } \\
\text { long line }\end{array}$} & \multirow{2}{*}{$\begin{array}{l}\text { Stationary lift } \\
\text { net }\end{array}$} \\
\hline & & & & & & & \\
\hline \multirow{4}{*}{1} & Ecological & 45.89 & 48.82 & 46.94 & 42.53 & 51.61 & 35.14 \\
\hline & The squared correlation value $\left(R^{2}\right)$ & 93.29 & 93.29 & 93.29 & 93.29 & 93.29 & 93.29 \\
\hline & Stress value/goodness of fit in MDS & 15.90 & 15.90 & 15.90 & 15.90 & 15.90 & 15.90 \\
\hline & Status of sustainability & Low & Low & Low & Low & Sufficient & Low \\
\hline \multirow{4}{*}{2} & Economic & 46.94 & 62.62 & 54.19 & 59.22 & 67.64 & 65.37 \\
\hline & The squared correlation value $\left(R^{2}\right)$ & 94.11 & 94.11 & 94.11 & 94.11 & 94.11 & 94.11 \\
\hline & Stress values/goodness of fit in MDS & 13.88 & 13.88 & 13.88 & 13.88 & 13.88 & 13.88 \\
\hline & Status of sustainability & Low & Sufficient & Low & Low & Sufficient & Sufficient \\
\hline \multirow{4}{*}{3} & Social & 47.55 & 41.87 & 65.40 & 49.32 & 72.34 & 34.69 \\
\hline & The squared correlation value $\left(R^{2}\right)$ & 90.55 & 90.55 & 90.55 & 90.55 & 90.55 & 90.55 \\
\hline & Stress value/goodness of fit in MDS & 15.00 & 15.00 & 15.00 & 15.00 & 15.00 & 15.00 \\
\hline & Status of level sustainability & Less & Less & Sufficient & Less & Sufficient & Less \\
\hline \multirow{4}{*}{4} & Technological & 51.74 & 59.49 & 54.61 & 42.13 & 60.04 & 34.02 \\
\hline & The squared correlation value $\left(R^{2}\right)$ & 90.30 & 90.30 & 90.30 & 90.30 & 90.30 & 90.30 \\
\hline & Stress value/goodness of fit in MDS & 17.15 & 17.15 & 17.15 & 17.15 & 17.15 & 17.15 \\
\hline & Status of sustainability & Sufficient & Sufficient & Sufficient & Bad & Sufficient & Bad \\
\hline \multirow{4}{*}{5} & Ethical & 47.81 & 50.84 & 52.33 & 49.85 & 74.46 & 45.55 \\
\hline & The squared correlation value $\left(R^{2}\right)$ & 92.68 & 92.68 & 92.68 & 92.68 & 92.68 & 92.68 \\
\hline & Stress value/goodness of fit in MDS & 19.56 & 19.56 & 19.56 & 19.56 & 19.56 & 19.56 \\
\hline & Status of sustainability & Less & Sufficient & Sufficient & Less & Sufficient & Less \\
\hline
\end{tabular}

Level of sustainability of fishery resources in Pangandaran, West Java can be seen in Table 2. As shown in the table, the ecological dimension of demersaldanish seine fishery, beach seine fishery, set gill nets fishery, trammel nets fishery and stationary lift net fishery was found to be less supportive to the sustainability fisheries resources. Mean while, the drift long line fishing gear was found to be relatively favorable for sustaining the fishery resources in the area. For this dimension, the coefficient of determination $\left(R^{2}\right)$ is $93.29 \%$, which means that the ecological dimension has a strong influence and relevance to the sustainability of fisheries resource management.

From the economic dimension point of view, demersaldanish seine, set gill nets and trammel nets are unfavorable to sustainability of fishery resources. Beach seine, drift long line and stationary lift net, on the other hand are sufficiently supportive to sustainability of fisheries resource in Pangandaran. The $R^{2}$ value for this dimension is $94.11 \%$, meaning that the economic dimension has a strong link to the sustainability of fisheries resource management.

From the social dimension point of view, it is found that demersaldanish seine, beach seine, trammel nets and stationary lift net are unfavorable to sustainability of fisheries resource. Mean while, set gill nets and other drift long line are in the state of sufficient to support the sustainability of fisheries resource management. For this dimension, the $R^{2}$ value is $90.55 \%$, meaning that the social dimension has a strong influence and relevance to the sustainability of fisheries resource management.

For the technological dimension, it was found that trammel nets and stationary lift net fisheries are in bad condition (very unsustainable), while demersaldanish seine, beach seine, set gill nets and other drift long line fisheries are in the state of sufficiently sustainable. The $R^{2}$ value of this dimension is $90.30 \%$, which means that the dimension of technology influences and has the relevance to the level of fisheries sustainability in 
Pangandaran.

Ethical dimension analysis indicates that demersaldanish seine, beach seine and stationary lift net show low support to sustainability while beach seine, set gill nets and other drift long line fisheries are in the state of sufficiently sustainable. For this dimension, $R^{2}$ value is $92.68 \%$, meaning that ethical dimension has an influence and a strong link to the sustainability of fisheries in Pangandaran.

\section{Conclusions}

Level of sustainability of fisheries in Pangandaran is categorized into "low" for the ecological, social, technological and ethical dimensions. In the mean time, the economic dimension is sufficiently to supportive the sustainability. From leverage analyses, it was identified that to improve the sustainability status of those dimensions, several attributes should receive special attention. For ecological dimension, these attributes are primary production, exploitation status, recruitment variability. For social dimension, these attributes are socialization of fishing, new entrants to the fishery and kin participation. For economic dimension, these attributes are average wage, profitability and subsidy. For technological dimension, these attributes are landing site, gear side effects, and finally, for the ethical dimension, these attributes are discard \& waste, just management and adjacency \& reliance.

\section{References}

[1] West Java Province Fisheries Statistics Year 1999-2010, Department of Marine and Fisheries in West Java, Marine and Fisheries Agency of West Java Province, Bandung, 1999-2010.

[2] H. Matsuda, Development of an adaptive marine ecosystem management and co-management plan at the Shiretoko World Natural Heritage Site [Online], www.elsiver.com/located/biocon (accessed Oct. 28, 2009).

[3] E.H. Allison, F. Ellis, The livelihoods approch and management of small-scale fisheries [Online], www.elseiver.com/loceted/marpol (accessed Oct. 28, 2009).

[4] A. Nurhayati, Influence of economic behavior of fishermen on the level sustainability of fishery resources, Dissertation, Padjadjaran University, 2011.

[5] T.J. Pitcher, M.P. Power, Fish figures: Quantifying the ethical status of Canadian fisheries, East and West, in: H. Coward, R. Ommer, T.J. Pitcher (Eds.), Just Fish: The Ethics of Canadian Fisheries, Institute of Social and Economic Research Press, St John's, Newfoundland, 1999. (in press)

[6] T.J. Pitcher, M.P. Power, Fish figures: Quantifying the ethical status of Canadian fisheries, East and West, in: H. Coward, R. Ommer, T.J. Pitcher (Eds.), Just Fish: the Ethics of Canadian Fisheries, Institute of Social and Economic Research Press, St John's, Newfoundland, 1999. (in press)

[7] T.J. Pitcher, D.B. Preikshot, Rapfish: A rapid appraisal technique to evaluate the sustainability status of fisheries, in: J. Craig (Ed.), ICLARM Workshop on Lake Nasser's Fisheries, 1999.

[8] The Development and Use of Indicators for Sustainable Development of Marine Capture Fisheries, FAO Technical Guidelines for Responsible Fisheries, No. 8, FAO, Rome, 1999, p. 79. 